\title{
TEGAL BESAR BEACH REHABILITATION WITH SCALLOPED CONCRETE BLOCK REVETMENT
}

\author{
Ni Nyoman Pujianiki, Gusti Ngurah Kerta Arsana, Gde Rai Putra Arya Simpangan \\ Program Studi Teknik Sipil, Fakultas Teknik Universitas Udayana \\ Email:pujianiki@civil.unud.ac.id
}

\begin{abstract}
Klungkung has a coastline of $113 \mathrm{~km}$ out of a total of $5780.06 \mathrm{~km}^{2}$ the coastline in the province of Bali, but about $25 \mathrm{~km}$ is eroded. One of the critical areas occurs in Tegal Besar beach which caused erosion of 0.08875 to $3.0915 \mathrm{~m} / \mathrm{yr}$. Revetment with scalloped concrete blocks is expected to protect land from the wave attack. Concrete blocks have uniform size and shape, showing the aesthetic aspect so as not damage the beauty of the beach. Analysis of wind, tidal, bathymetry and soil data are carried out to obtain the structure and stability of the revetment. The results of this design can be used to rehabilitate the condition of the Tegal Besar beach. From the analysis, the design wave height with a return period of 25 years $\left(H_{25}\right)=0.891 \mathrm{~m}$, while the height with the breaking wave $(\mathrm{Hb})$ $=1.003 \mathrm{~m}$ and the breaking wave depth $(\mathrm{db})=1.068 \mathrm{~m}$ and the design water level elevation $(D W L)=$ $2.061 \mathrm{~m}$ calculated from MSL. The revetment structure has a height of $4.00 \mathrm{~m}$, a peak width of $1.50 \mathrm{~m}$, the weight of the first layer of protection is $300 \mathrm{~kg}$ and the second is $30 \mathrm{~kg}$ with a thickness of $1.00 \mathrm{~m}$. Toe protection are $1.25 \mathrm{~m}$ high, $3.00 \mathrm{~m}$ wide and weigh $150 \mathrm{~kg}$. The results showed that the revetment was stable against overturning, shearing, and the bearing capacity of the soil was declared safe with the results of overturning stability 22,075 > 2, slidding stability $2.249>1.5$ and the bearing capacity of the soil 57,993 > 3 so that the revetment can be eligible to be applied at the site.
\end{abstract}

Keywords: revetment, Tegal Besar beach, erosion, scalloped concrete blocks

\section{REHABILITASI PANTAI TEGAL BESAR DENGAN REVETMENT BLOK BETON BERGIGI}

ABSTRAK: Kabupaten Klungkung memiliki garis pantai sepanjang $113 \mathrm{~km}$ dari total 5780,06 km² garis pantai di Provinsi Bali, namun sekitar $25 \mathrm{~km}$ mengalami erosi pantai. Salah satu daerah kritis terjadi di pantai Tegal Besar yang menyebabkan erosi sebesar 0,08875 hingga 3,0915 m/th. Revetment dengan blok beton bergigi diharapkan dapat melindungi daratan dari serangan gelombang. Blok beton memiliki ukuran dan bentuk yang seragam, menunjukkan aspek estetika sehingga tidak merusak keindahan pantai. Analisis data angin, pasang surut, batimetri dan tanah dilakukan untuk mendapatkan struktur dan stabilitas revetment. Hasil perencanaan ini dapat digunakan untuk merehabilitasi kondisi pantai Tegal Besar. Dari hasil analisa, tinggi gelombang rencana dengan kala ulang 25 tahun $\left(\mathrm{H}_{25}\right)=$ $0,891 \mathrm{~m}$, sedangkan tinggi gelombang pecah $(\mathrm{Hb})=1,003 \mathrm{~m}$ dan kedalaman gelombang pecah $(\mathrm{db})=$ $1,068 \mathrm{~m}$ dan muka air rencana level elevasi $(\mathrm{DWL})=2,061 \mathrm{~m}$ dihitung dari MSL. Struktur revetment memiliki tinggi 4,00 m, lebar puncak $1,50 \mathrm{~m}$, berat lapisan pelindung pertama $300 \mathrm{~kg}$ dan lapisan kedua $30 \mathrm{~kg}$ dengan ketebalan 1,00 m. Pelindung kaki memiliki tinggi 1,25 m, lebar 3,00 m, dan berat $150 \mathrm{~kg}$. Hasil penelitian menunjukkan bahwa revetment stabil terhadap guling, geser, dan daya dukung tanah dinyatakan aman dengan hasil stabilitas guling $22.075>2$, stabilitas geser $2.249>1.5$ dan daya dukung tanah $57.993>3$ sehingga revetment memenuhi syarat untuk diterapkan di lokasi.

Kata kunci: revetment, Pantai Tegal Besar, erosi, blok beton bergigi 


\section{INTRODUCTION}

Bali is one of the provinces in Indonesia which is famous for its scenery and the coastal area with a coastline of $633.35 \mathrm{~km}$. However, currently, more than $215.82 \mathrm{~km}$ of coastline in Bali has been identified as experiencing erosion. Coastal erosion is a problem that threatens the existence of the coast, caused by a combination of factors such as sea level changes, storms, and human intervention (Kementrian Pekerjaan Umum Dan Perumahan rakyat, 2020). Causes of coastal damage due to human intervention, such as the reduced supply of sediment to the beach due to the construction of dams, mining of coral and sea sand and the construction of coastal protective structures (Zamdial et al., 2017). Beaches in Bali that experience moderate to critical erosion levels are in the southern part of Bali, including in Pengambengan (Jembrana Regency), Candidasa (Karangasem Regency), Padang Galak (Denpasar City), Lebih (Gianyar), Kuta (Badung), and Tegal Besar (Klungkung Regency). Coastal erosion in Klungkung and Gianyar regencies began to occur significantly from 2007-2017 (Hariyanto et al., 2018), (Aryastana et al., 2016), this also occurred in the coastal area of West Bali, marked by a decrease in coastline and damage to coastal buildings (Pujianiki et al., 2019).

Currently, the impact of erosion on the Tegal Besar beach is clearly visible from the changes in the coastline that occur. According to Nugraha et al., (2017), the rate of change of the coastline of Tegal Besar due to erosion ranges from 0.8875 to 3.09155 $\mathrm{m} / \mathrm{yr}$. To overcome the damage to the coastline due to coastal erosion, the government and the community have build a revetment. Revetment that has been built, is currently broken and is no longer functional as shown in Figure 1. Therefore, it is necessary to carry out alternative treatments to overcome coastal erosion that occurs in Tegal Besar Beach
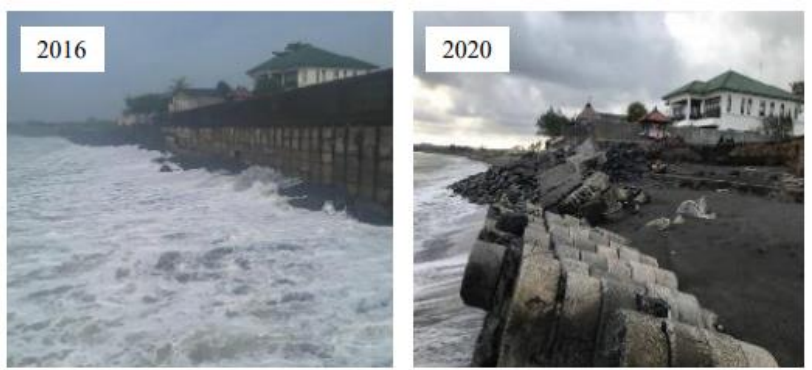

Figure 1 The existing revetment on the Tegal Besar beach in 2016 and year 2020
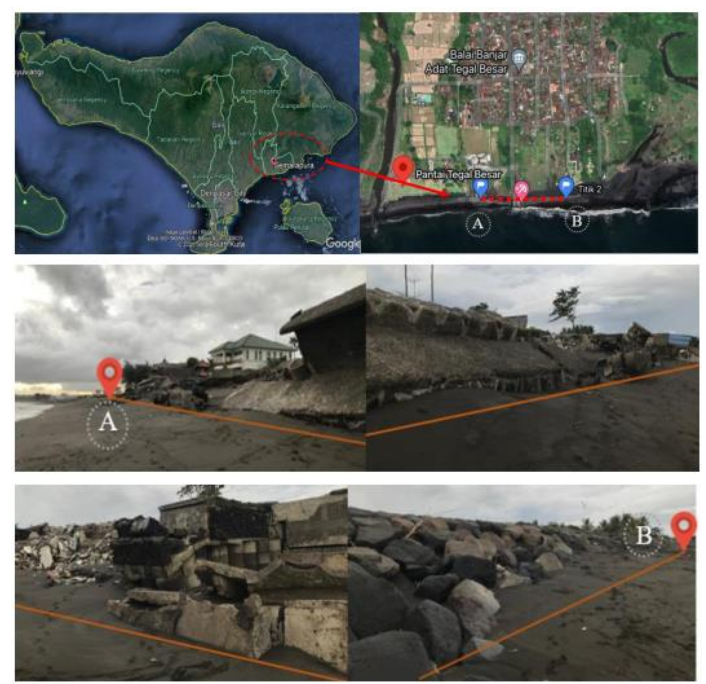

Figure 2 Tegal Bear Beach

Figure 2 shows location of the study. An alternative treatment for coastal erosion is urgently needed at Tegal Besar Beach. Therefore, it is necessary to re-plan the revetment using different materials. Materials used to redesign the revetment at Tegal Besar Beach is a scalloped concrete block. Scalloped concrete block has a lighter armor weight than precast concrete in general but has higher stability due to scalloped concrete blocks has a scalloped structure as a lock between the units so that doesn't happen shift in position between the concrete block units that are arranged. the results of planning with almost similar concrete blocks produce a fairly high stability of the structure (Sanjaya, 2020), (Putra et al., 2017). Attractive finish as the installed concrete blocks have uniform size and shape, showing the aesthetic aspect so as not to damage the beauty of the beach. Revetment with scalloped concrete blocks has been applied in several areas such as Happy Beach in Buleleng Bali and Muko-Muko Beach in Bengkulu, with result looks good provides an attractive aesthetic atmosphere so it is suitable for the beach which is a tourist attraction (Sulaiman, 2018). In this research, revetment planned with scalloped concrete blocks as an alternative in overcoming coastal problems what happened at Tegal Besar Beach so that it was a setback shoreline is not happening anymore.

\section{METHODS}

The planning stage begins with reviewing and observing the location, identifying problems, collecting data and analyzing data. In planning the revetment, it is necessary to collect data which includes 1) topographic maps and bathymetry to 
determine the depth of the seabed at that location, 2) wind, 3) tides, and 5) soil data.

The stages of data analysis used in this study are, 1) Wind Data Analysis to obtain wind speed correction (UA), 2) Fetch Length Analysis, and 3) Wave Analysis Calculation is carried out by calculating return wave calculations using the Weibull and Gumbel method, Calculation of Breaking Waves, Calculation of Design Waves, Calculation of Design Water Level, and Calculation of Revetment Dimensions.

\section{Wind Data Analysis and Fetch Calculation}

Based on wind data from the Meteorology, Climatology and Geophysics Agency in Bali, wind data is used for 10 years from 2010 to 2019 . Wind rose is made to get the most dominant wind direction and wind speed as shown in Figure 3. After knowing the dominant wind direction then proceed with the calculation of the corrected wind speed. The wind data used is the dominant wind data each year which then follows converted to units of $\mathrm{m} / \mathrm{s}$, where $1 \mathrm{knot}$ is $0.514 \mathrm{~m} / \mathrm{s}$, Wind data were analyzed to obtain wind speed correction $\left(\mathrm{U}_{\mathrm{A}}\right)$ using Eq. (1) and then Wind stress correction $\left(\mathrm{U}_{\mathrm{A}}\right)$ was used in wave forecasting.

The fetch is limited in the form of land surrounding the sea as measured by the potential distance of wave formation between the observation site and the surrounding islands, Tegal Besar Beach has a fetch to the east. Calculation of the effective fetch length $\left(\mathrm{F}_{\text {eff }}\right)$ using Eq (2). The calculation of the effective fetch length $\left(\mathrm{F}_{\text {eff }}\right)$ is then used in calculation of wave forecasting and calculation of water level elevation plan due to wind (wind set-up).

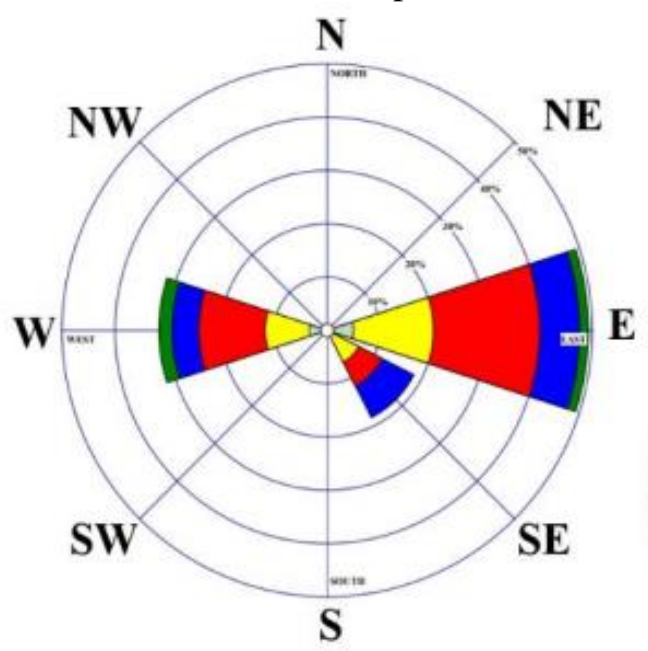

Figure 3. Windrose

$$
\begin{aligned}
& \mathrm{U}_{\mathrm{A}}=0,71 \mathrm{U} 1,23 \\
& \text { Feff }=\sum x i . \operatorname{Cos} \alpha / \sum \operatorname{Cos} \alpha
\end{aligned}
$$

\section{Wave Calculation}

Determining factors in the safety of coastal buildings from waves based on wave history, power proneness waves, and the possibility of tidal waves in a certain period (Mangare, 2016), therefore, need to be forecasting waves in the deep sea to find out the wave height significant (HS) and significant wave period (TS) can be calculated based on corrected wind speed (UA) and effective fetch length using Eq. (3) and (4) as follows:

$\mathrm{Hs}=0,0016\left(\frac{U_{A}{ }^{2}}{g}\right)\left(\frac{g \cdot F e f f}{U_{A}{ }^{2}}\right)^{\frac{1}{2}}$

$\mathrm{TS}=0,2857\left(\frac{U_{A}}{g}\right)\left(\frac{g \cdot \text { Feff }}{U_{A}{ }^{2}}\right)^{1 / 3}$

The propagation of waves from the deep water to the coast changes shape due to changes in sea depth, then the calculation of breaking waves can use the following equation.

$$
\begin{aligned}
& \frac{H_{b}}{H_{o}}=\frac{1}{3,33\left(H_{o} / L_{o}\right) \frac{1}{3}} \\
& \frac{d_{b}}{H_{b}}=\frac{1}{b-\left(a \cdot H_{b} / g \cdot T^{2}\right)}
\end{aligned}
$$

\section{Run-Up}

The wave run-up value will be used to determine the peak elevation of the revetment, using the following equation:

$$
\operatorname{Ir}=\frac{\operatorname{tg} \theta}{\left(\frac{H_{b}}{L_{0}}\right)^{0,5}}
$$

\section{Sea Level Rise}

The increase in water level due to global warming can be calculated using Figure 4 below, there are estimates of sea level rise from 1990 to 2100 .

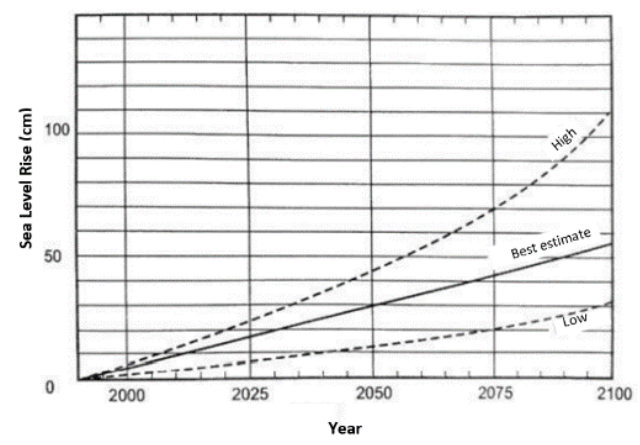

Figure 4. Estimated sea level rise due to global warming (Triatmodjo, 2011)

\section{Protected Layer Stones}

The thickness of the main protective stone and the second protective stone as well as the core layer is given by the following formula:

$\mathrm{t}=n K_{\Delta}\left[\frac{W}{\gamma_{r}}\right]^{1 / 3}$ 
While the amount of the main protected stone layer is given by the following equation:

$$
\mathrm{N}=\mathrm{A} \mathrm{n}_{\Delta}\left[1-\frac{P}{100}\right]\left[\frac{\gamma_{r}}{W}\right]^{2 / 3}
$$

\section{Toe Protection}

The weight of the toe protection on the revetment is given by the following equation:

$\mathrm{W}=\frac{\gamma r H^{3}}{N s^{3}(S r-1)^{3}}$

\section{RESULT AND DISCUSSION \\ Return Period Analyze}

Based on the calculation results, the maximum wave at Tegal Besar Beach with a return period of 25 years, the wave height $\left(\mathrm{H}_{25}\right)=0.996 \mathrm{~m}$ with the wave period $\left(T_{25}\right)=4.624 \mathrm{~s}$ is obtained. Therefore, the results of this calculation will be used in the calculation of the design wave.

\section{Calculation of the Length and Speed of Wave Propagation in Deep Sea}

Calculation of the wavelength in the deep sea $\left(\mathrm{L}_{\mathrm{o}}\right)$, and the speed of wave propagation in the deep sea $\left(\mathrm{C}_{\mathrm{o}}\right)$ can be calculated below:

$$
\begin{aligned}
& \mathrm{L}_{\mathrm{o}}=\frac{g T^{2}}{2 \pi}=1,56 \times \mathrm{T}^{2} \\
& \mathrm{~L}_{\mathrm{o}}=\frac{9,81 \mathrm{~m} / d t^{2} x(4,624 d t)^{2}}{2 \times 3,14}=33,381 \mathrm{~m} \\
& \mathrm{C}_{\mathrm{o}}=\frac{g T}{2 \pi}=1,56 \times \mathrm{T} \\
& \mathrm{C}_{\mathrm{o}}=\frac{9,81 \mathrm{~m} / d \mathrm{t}^{2} x 4,624 d t}{2 \times 3,14}=7,219 \mathrm{~m} / \mathrm{dt}
\end{aligned}
$$

The wavelength in the deep sea $\left(\mathrm{L}_{\mathrm{o}}\right)$ and the wave propagation speed in the deep sea $\left(\mathrm{C}_{\mathrm{o}}\right)$ are then used to calculate the design wave height.

\section{Calculation of Design Wave Height}

Based on the topographic map and bathymetry of Tegal Besar Beach, at a depth $(\mathrm{d})=2 \mathrm{~m}$, the design wave height is calculated using the following equation (1):

$\mathrm{H}_{0}=\mathrm{Ks}$. Kr. $\mathrm{H}_{25}$

$\mathrm{H}_{0}=0.993 \times 0.901 \times 0.996=0.891 \mathrm{~m}$

$\mathrm{H}_{0}=0.891 \mathrm{~m}$ (from the results of wave forecasting obtained in 2021 higher than the forecast on the coast of Tegal Besar Beach in the previous study of $0.768 \mathrm{~m}$ (Suryawan et al., 2019) but requirements for the design wave height for the use of scalloped concrete blocks is $1.5 \mathrm{~m}$, then armored scalloped concrete beams can be applied). The design wave height is $\mathrm{H}_{0}=0.891 \mathrm{~m}$ which is then used in breaking wave analysis (Indrasari, 2020).

\section{Wave Breaking Calculation}

The waves propagate from the deep sea to the coast, changing shape due to the influence of changes in sea depth. Calculation of breaking waves can be seen in the calculations below:

The equivalent sea wave height at a depth of $2 \mathrm{~m}$ is calculated using the equation:

$\mathrm{H}_{0}^{\prime}=\mathrm{Kr} \times \mathrm{H}_{0}$

$\mathrm{H}_{0}^{\prime}=0.901 \times 0.891$

$\mathrm{H}_{0}^{\prime}=0.801 \mathrm{~m}$

by entering the value $\frac{\mathrm{H}_{0}^{\prime}}{g T^{2}}=0,0038$ on the chart and drawing a line that corresponds to the slope of Tegal Besar beach based on a batimetry $(\mathrm{m}=0.033)$, we can obtain the value of $\frac{H_{b}}{\mathrm{H}_{0}^{\prime}}$ as shown in Figure 5 below:

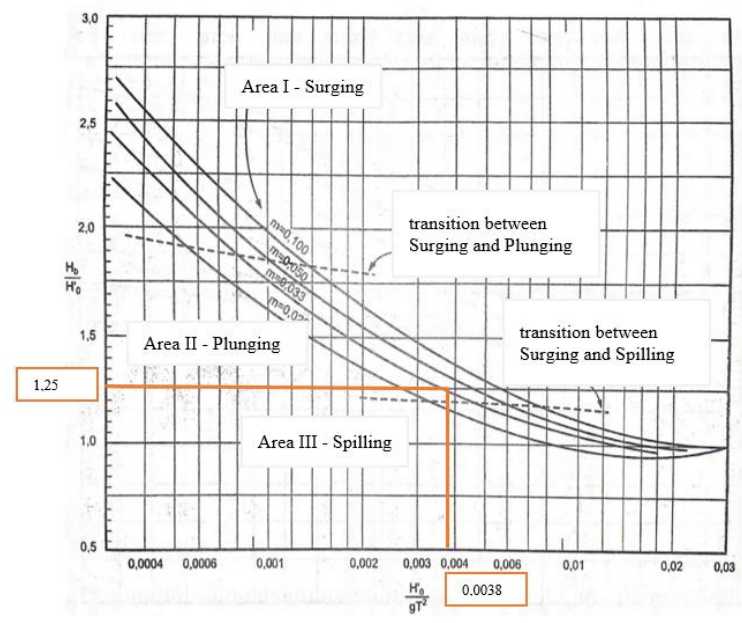

Figure 5. Graph of determination of the height of the wave breaking $\left(\mathrm{H}_{\mathrm{b}}\right)$ (Triatmodjo, 2011)

From the graph in Figure 5 above, it can be seen that:

$$
\begin{array}{ll}
\frac{H_{b}}{\mathrm{H}_{0}^{\prime}} & =1,25 \\
\mathrm{H}_{\mathrm{b}} & =\mathrm{H}^{\prime}{ }_{0} \times 1,25 \\
\mathrm{H}_{\mathrm{b}} & =0,802 \times 1,25=1,003 \mathrm{~m}
\end{array}
$$

The $\mathrm{Hb}$ value obtained is used to calculate the depth of the broken wave. From Figure 6 depth of the broken wave can be obtain:

$$
\begin{aligned}
& \frac{d_{b}}{H_{b}}=1,08 \\
& d_{b}=1,08 \times H_{b}=1,08 \times 1,003=1,068 m
\end{aligned}
$$




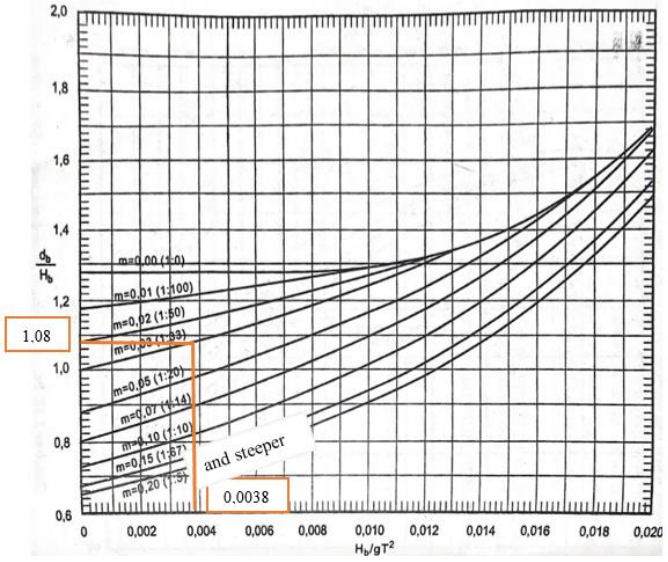

Figure 6. Graph of determination of the depth of the wave breaking $\left(\mathrm{d}_{\mathrm{b}}\right)$ (Triatmodjo, 2011)

\section{Water Level Analyze}

Water level elevation is an important parameter in design coastal structure. The elevation is the sum of several parameters such as Tidal wave, Sea level rise due to waves / Wave set up (Sw), Sea level rise due to wind / Wind set up $(\Delta \mathrm{h})$, Global Warming (SLR). Tidal data is obtained from the Department of Work General Bali-Penida, so that the water level is obtained as following:

- $\mathrm{HWL}=+1.35 \mathrm{~m}$

- $\mathrm{MSL}= \pm 0.00 \mathrm{~m}$

$-\quad$ LWL $=-1.35 \mathrm{~m}$

Wave set up ( $\mathrm{Sw})$ is calculated using the equation (7):

$\mathrm{S}_{\mathrm{w}}=0,19\left[1-2,82 \sqrt{\frac{H_{b}}{g T^{2}}}\right] H_{b}$

$\mathrm{S}_{\mathrm{w}}=0,19\left[1-2,82 \sqrt{\frac{1,003 \mathrm{~m}}{9,81 \mathrm{~m} / d t^{2} x(4,624 d t)^{2}}}\right] 1,003 \mathrm{~m}$

$\mathrm{S}_{\mathrm{w}}=0,153 \mathrm{~m}$

From the calculation of Feff Length $=42647,837$ $\mathrm{km}$, wind set up value $(\Delta \mathrm{h})$ is:

$\Delta \mathrm{h}=F \cdot c \cdot \frac{V^{2}}{2 \cdot g \cdot d}$

$\Delta \mathrm{h}=42647,837 \mathrm{~m} \times 3,5 \times 10^{-6} \times \frac{(8,540 \mathrm{~m} / \mathrm{dt})^{2}}{2 \times 9,81 \mathrm{~m} / \mathrm{dt} t^{2} \times 2 \mathrm{~m}}$

$\Delta \mathrm{h}=0,277 \mathrm{~m}$

The revetment is designed to have a use life of 25 years from 2021 to 2046 so that by using the graph on Figure 4, seawater rise due to global warming is $28 \mathrm{~cm}=0.28 \mathrm{~m}$. So, Design Water Level can be calculated using the following equation:

$\mathrm{DWL}=\mathrm{HWL}+\mathrm{Sw}+\Delta \mathrm{h}+\mathrm{SLR}$

DWL $=1,35+0,153+0,227+0,28$

DWL $=2,061 \mathrm{~m}$

\section{Revetment Structure Design}

The main structure of the revetment using scalloped concrete blocks in this plan is designed to have a slope of 1:2 so that the run-up height is obtained as follows:

$\operatorname{Ir}=\frac{\operatorname{tg} \theta}{\left(H / L_{o}\right)^{0,5}}$

$\operatorname{Ir}=\frac{0,5}{(0,801 \mathrm{~m} / 33,381 \mathrm{~m})^{0,5}}=3,060$

The run-up revetment value of the scalloped concrete armor block material with $\mathrm{KD}=4$ has the same value as the crushed stone material, then runup wave value is obtained as follows:

$$
\begin{array}{ll}
\frac{R u}{H} & =1,125 \\
\mathrm{Ru} & =1,125 \times 0,801=1,002 \mathrm{~m}
\end{array}
$$

so that the height of the crest or peak revetment can be calculated as follows:

$$
\begin{aligned}
& \mathrm{El}_{\text {revetment }}=\mathrm{DWL}+\mathrm{Ru}+\mathrm{Fb} \\
& \mathrm{El}_{\text {revetment }}=2,061+1,002+0,5 \\
& \mathrm{El}_{\text {revetment }}=3,563 \approx 4 \mathrm{~m}
\end{aligned}
$$

Calculation of the weight of the protected layer based on the Hudson formula, where scalloped concrete block with concrete density $=2.4 \mathrm{ton} / \mathrm{m}^{3}$ and seawater density $=1.03 \mathrm{ton} / \mathrm{m}^{3}$, so:

$$
\begin{aligned}
\mathrm{Sr} & =\frac{\gamma r}{\gamma \alpha} \\
\mathrm{Sr} & =\frac{2,4 \text { ton } / \mathrm{m}^{3}}{1,03 \text { ton } / \mathrm{m}^{3}}=2,341 \\
\mathrm{~W}_{1} & =\frac{\gamma r \cdot H^{3}}{K D(S r-1)^{3} \cot \theta} \\
\mathrm{W}_{1} & =\frac{2,4 \operatorname{ton} / \mathrm{m}^{3} x(0,891 \mathrm{~m})^{3}}{4 x(2,341-1)^{3} \times 2}=0,088 \text { ton } \approx 0,3 \text { ton }
\end{aligned}
$$

Based on the specifications of scalloped concrete blocks weighing 0.3 tons and the calculated weight $=$ 0.088 tons $<0.3$ tons, then weight of scalloped concrete blocks can be used in planning. Calculation of the weight and thickness of the second protected layer:

$$
\begin{aligned}
& \mathrm{w}_{2}=\frac{W}{\mathbf{1 0}}=\frac{\mathbf{0 . 3}}{\mathbf{1 0}}=0,03 \text { ton }=30 \mathrm{~kg} \\
& \mathrm{t}_{2}=n k_{\Delta}\left[\frac{w}{y_{r}}\right]^{1 / 3} \\
& \mathrm{t}_{2} \quad=2.1,15\left[\frac{0,3}{2,4}\right]^{1 / 3}=0,534 \mathrm{~m} \approx 1 \mathrm{~m}
\end{aligned}
$$

Calculation of the fill layer (Core layer)

$$
\begin{aligned}
\mathrm{w}_{2} & =\frac{W}{200}=\frac{\mathbf{0 , 3}}{200}=0,03 \text { ton }=0,0015 \mathrm{~kg} \\
& =1,5 \mathrm{~kg}
\end{aligned}
$$

Revetment peak width calculation based on the layer coefficient $\mathrm{K}_{\Delta}=1.15$, the number of stone grains minimum, $(\mathrm{n})=2$.

$$
\begin{aligned}
& \mathrm{B}=n k_{\Delta}\left[\frac{W}{y r}\right]^{1 / 3} \\
& \mathrm{~B}=2.1,15\left[\frac{0,30}{2,14}\right]^{1 / 3}=1,15 \approx 1,5
\end{aligned}
$$


with a porosity value $(\mathrm{P})=37 \%$ so that the total number of protective stones for one unit area $\left(10 \mathrm{~m}^{2}\right)$ can be calculated:

$$
\begin{aligned}
& \mathrm{N}=A \cdot n \cdot K_{\Delta}\left(1-\frac{P}{100}\right)\left(\frac{\gamma r}{W}\right)^{2 / 3} \\
& \mathrm{~N}=10 \cdot 2 \cdot 1,15\left(1-\frac{37}{100}\right)\left(\frac{2,4}{0,3}\right)^{2 / 3} \\
& \mathrm{~N}=57,96 \approx 58 \text { blocks }
\end{aligned}
$$

\section{Toe Protection}

The base elevation of the revetment is planned at a depth of -1.25 meters calculated from MSL $( \pm 0.00)$. Water level at the revetment $(\mathrm{ds})$ of $\mathrm{HWL}=+1.35$ $\mathrm{m}$ from the base elevation revetment is -1.25 , so $\mathrm{ds}=$ $1.35+1.25=2.60 \mathrm{~m}$. Then the thickness of the toe protection calculation:

- The thickness of the first protective layer $\left(\mathrm{t}_{1}\right)=$ $1.50 \mathrm{~m}$

- The thickness of the second protective layer $\left(\mathrm{t}_{2}\right)$ $=1.00 \mathrm{~m}$

$$
\mathrm{T}=\mathrm{r}=\frac{(\mathbf{1}, \mathbf{5 0}+\mathbf{1 , 0 0})}{\mathbf{2}}=1,25 \mathrm{~m}
$$

Calculation of the width of the toe protection using the equation $\mathrm{B}=3 \mathrm{H}-4.5 \mathrm{H}$ where in this design the width is set equal to $3 \mathrm{H}$ so width of toe protection:

$\mathrm{B}=3 \mathrm{H}$

$\mathrm{B}=3 \times 0,891=2,673 \approx 3,00 \mathrm{~m}$

Toe protection stability control using graphics stability number $\left(\mathrm{Ns}^{3}\right)$ for foundation and foot protection in Figure 7.

$\mathrm{ds}=2,60 \mathrm{~m}$

$\mathrm{d} 1=2,60-1,25=1,35 \mathrm{~m}$

$\mathrm{d} 1 / \mathrm{d} s=1,35 / 2,60=0,519$

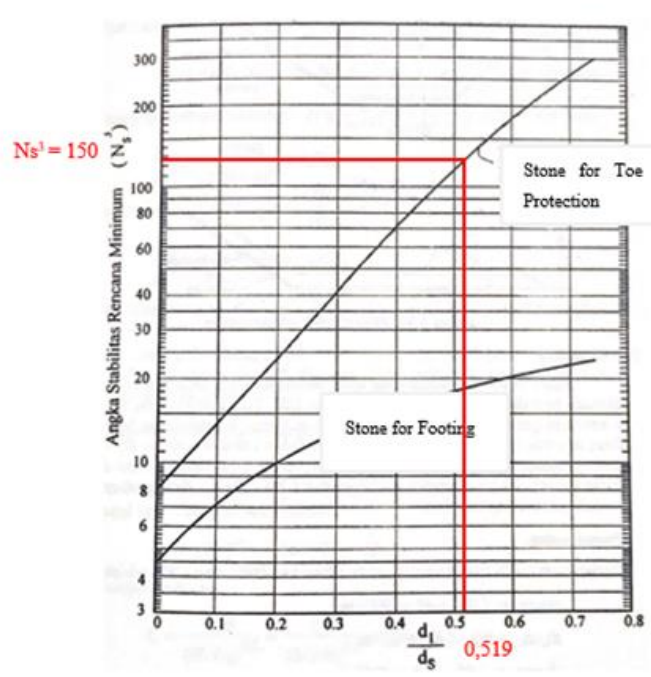

Figure 7. Graph of determining the stability value $\left(\mathrm{Ns}^{3}\right)$ for toe protection (Triatmodjo, 2011)
The weight of the stone for toe protection is calculated using the following equation:

$$
\begin{array}{ll}
\mathrm{W} & =\frac{\gamma r \cdot H^{3}}{N s^{3}(S r-1)^{3}} \\
\mathrm{~W} & =\frac{2,4 \operatorname{ton} / \mathrm{m}^{3} x(0,891 \mathrm{~m})^{3}}{150 x(2,341-1)^{3}}=0,00703 \text { ton }
\end{array}
$$

The weight of the toe protection stone can be an extension of the thickness of the protective wall layer, so that its weight is half of the weight The thickness of the protective wall layer is $\mathrm{W} / 2$.

$$
\begin{aligned}
& \mathrm{W}=\frac{W}{2} \\
& \mathrm{~W}=\frac{0,3 \text { ton }}{2} \\
& \mathrm{~W}=0,15 \text { ton }=150 \mathrm{~kg}
\end{aligned}
$$

The final design of the revetment can be seen in Figure 8

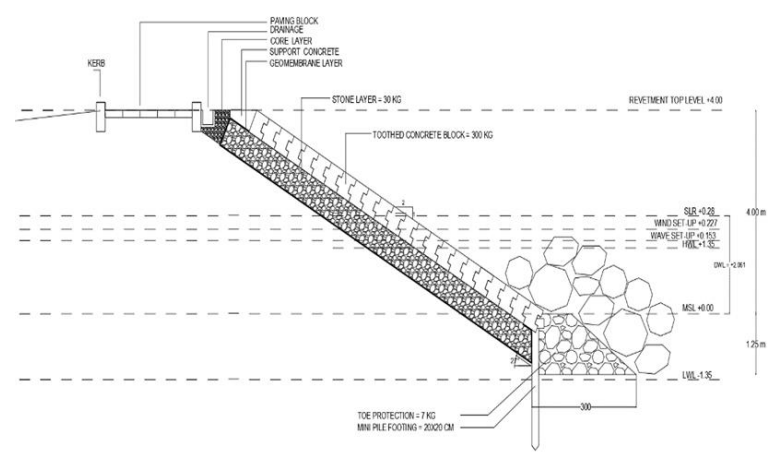

Figure 8. Revetment design with scalloped concrete blocks

\section{Soil Data Analyze}

Saba beach soil data was used in the analysis of soil data because it has the same characteristics as the Tegal Besar beach obtained from the Bali-Penida River Basin Center. Based on the above soil characteristic parameters with revetment width $(\mathrm{B})=$ $12.9 \mathrm{~m}$, it can be calculated the value of the soil boundary strength (Qult) with the Terzaghi equation (Muda, 2016):

$\mathrm{Q}_{\text {ult }}=\mathrm{C} \cdot \mathrm{N}_{\mathrm{c}}+\mathrm{D}_{\mathrm{f}} \cdot \gamma \cdot \mathrm{N}_{\mathrm{q}}+0,5 \mathrm{~B} \cdot \gamma \cdot \mathrm{N}_{\gamma}$

$\mathrm{Q}_{\text {ult }}=0,089.27,52+2.2,953.14,66+0,5(12,9)$.

$$
2,953.11,7
$$

$\mathrm{Q}_{\mathrm{ult}}=274,21 \mathrm{t} / \mathrm{m}^{2}$

Control of revetment structure stability, from the Figure 9 obtained $\Sigma \mathrm{Mv}=269.204 \mathrm{tm}, \Sigma \mathrm{MH}=12.195$ $\mathrm{tm}, \Sigma \mathrm{V}=45.134 \mathrm{~m}, \Sigma \mathrm{H}=8.029$. The value of the shear coefficient ( $\mu \mathrm{s})$ is taken from 0.4-0.5.

Overturning stability $=\frac{\sum \mathrm{MV}}{\sum \mathrm{MH}}>2$

Sliding stability

$$
\begin{aligned}
& =\frac{\sum \mathrm{MH}}{269,204}=22,075>2 \\
= & \frac{\sum \mathrm{Vx \mu s}}{\sum \mathrm{H}}>1,195 \\
= & \frac{45,134 \mathrm{x} 0,5}{8,029}=2,249>1,5
\end{aligned}
$$


The results of the calculation of the stability of the revement against overturning and shear indicate that the building is safe from the forces acting on the building.

Stability Control of Soil Bearing Capacity:

Eccentricity value is calculated as follow

$$
\begin{aligned}
\mathrm{e} & =\frac{\mathrm{B}}{2}-\left(\frac{\sum \mathrm{MV}-\sum \mathrm{MH}}{\sum \mathrm{V}}\right)<\frac{\mathrm{B}}{6} \\
& =\frac{12,9}{2}-\left(\frac{269,204-12,195}{45,134}\right)<\frac{12,9}{6} \\
& =0,756<2,15
\end{aligned}
$$

Calculation of the soil stress $\mathrm{Q}_{\max }$ and $\mathrm{Q}_{\min }$ to determine the most significant soil stress value at the revetment location by:

$$
\begin{aligned}
& \mathrm{Q}=\frac{\Sigma V}{B} x\left(1 \pm\left(\frac{6 e}{B}\right)\right) \\
& \mathrm{Q}_{\max }=\frac{45,134}{12,9} x\left(1+\left(\frac{6 x(0,756)}{12,9}\right)\right)=4,728 \mathrm{t} / \mathrm{m}^{2}<274,21 \\
& \mathrm{t} / \mathrm{m}^{2} \\
& \mathrm{Q}_{\min }=\frac{45,134}{12,9} x\left(1-\left(\frac{6 x(0,756)}{12,9}\right)\right)=2,269 \mathrm{t} / \mathrm{m}^{2}<274,21 \\
& \mathrm{t} / \mathrm{m}^{2}
\end{aligned}
$$

After getting the largest soil stress value Qmax, then the stability of the bearing capacity of the soil is calculated.

$$
\begin{aligned}
& \frac{\mathrm{Q}_{\text {ult }}}{\mathrm{Q}_{\max }}>3 \\
& \frac{274,21}{4,728}>3 \\
& 57,993>3
\end{aligned}
$$

The results of the calculation of the stability of the bearing capacity of the soil at the building site are declared safe with a stability value of $=57.993$, which is greater than the number of safety factors, which is 3 (Hardiyatmo, 2018; Indriasari, 2018), because it is more influenced by soil characteristics, generally the value of soil bearing capacity produced far exceeds that of safety factor (Indriasari, 2018).

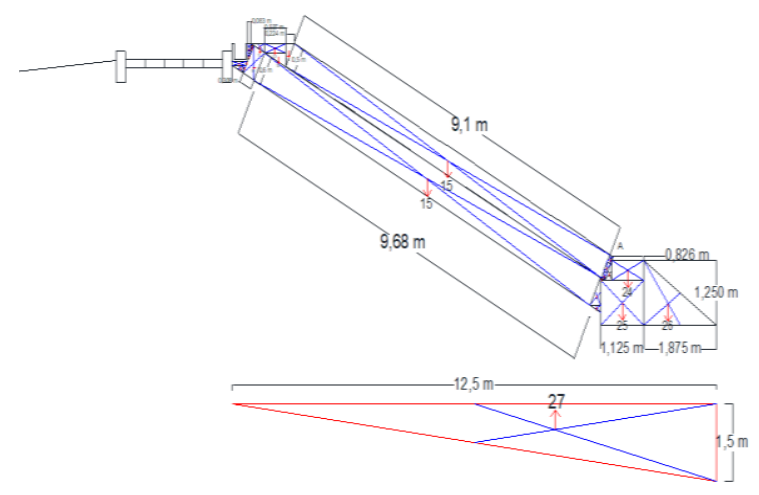

Figure 9. Forces that work on revetment

\section{CONCLUSIONS}

Based on the results of the analysis, the revetment with scalloped concrete blocks can be applied to rehabilitate the Tegal Besar beach which was previously protected by revetment but has been damaged. The revetment structure has a height of $4.00 \mathrm{~m}$, a peak width of $1.50 \mathrm{~m}$, the weight of the first layer of protection is $300 \mathrm{~kg}$ and the second is $30 \mathrm{~kg}$ with a thickness of $1.00 \mathrm{~m}$. Toe protection are $1.25 \mathrm{~m}$ high, $3.00 \mathrm{~m}$ wide and weigh $150 \mathrm{~kg}$. The results showed that the revetment was stable against overturning, shearing, and the bearing capacity of the soil was declared safe with the results of overturning stability $22,075>2$, shear stability $2.249>1.5$ and the bearing capacity of the soil $57,993>3$ so that the revetment can be eligible to be applied at the site.

\section{REFERENCES}

Aryastana, P., Eryani, I., \& Candrayana, K. 2016. Perubahan Garis Pantai dengan Citra Satelit di Kabupaten Gianyar. Paduraksa, 5(2).

Hardiyatmo, H. C.. 2018. "Mekanika Tanah II" edisi 6, Yogyakarta, Gadjah Mada University Press.

Hariyanto, T., Mukhtar, M. K., \& Pribadi, C. B. 2018. Evaluasi Perubahan Garis Pantai Akibat Abrasi Dengan Citra Satelit Multitemporal (Studi Kasus: Pesisir Kabupaten Gianyar, Bali). Geoid, 14(1).

Indriasari, V. Y., Risandi, J. and Akhwady, R. 2018. "Karakteristik Dan Daya Dukung Tanah Untuk Struktur Perlindungan Pantai Di Pantai Kedungu, Kabupaten Tabanan Provinsi Bali" Jurnal Teknik Sipil Universitas Syiah Kuala, vol. 5, no. 3, pp. 251-258, 2018.

Kementrian Pekerjaan Umum Dan Perumahan rakyat. 2020. Pekerjaan Pembangunan Pengamanan Pantai Ruas Tegal Besar Lepang di Kabupaten Klungkung.

Mangare, J. B. 2016. Penerapan Metode Analyical Hierarchy Process Untuk Pemilihan Sistem Pengamanan Pantai. Jurnal Sipil Statik, 4(11).

Muda, A. 2016. Analisis Daya Dukung Tanah Fondasi Dangkal Berdasarkan Data Laboratorium. Jurnal ITEKNA, 16(1).

Nugraha, I. N. J., Karang, I. W. G. A., \& Dharma, I. G. B. S. 2017. Studi Laju Perubahan Garis Pantai di Pesisir Tenggara Bali Menggunakan Citra Satelit Landsat (Studi Kasus Kabupaten Gianyar dan Klungkung). Journal of Marine and Aquatic Sciences, 3(2), 204.

Pujianiki, N. Y., Ketut, S., \& Saputra, A. C. 2019. Revitalizing the Batu Mejan Beach with Geotextile Breakwater. IOP Conference Series: Earth and Environmental Science, 248(1). 
Pujianiki, N. Y., Diputra, I. G. A, Jayantari, M. W. and Mataram, I. N. K. 2019. "Coastal Protection Work for Batu Mejan Beach, Bali", MATEC Web of Conferences, vol. 276, no. 04019.

Putra, I. K. S. W., Yujana, C. A., \& Surayasa, N. 2017. Perencanaan Bangunan Pengaman Pantai (Revetment) Dengan Bahan Geobag Di Pantai Masceti, Kabupaten Gianyar. 6 (2), 178-189.

Sanjaya, I. N. W. 2020. Perencanaan Revetment Dengan Blok Beton 3B (Berkait, Berongga Dan Bertangga) Di Pantai Batu Mejan Kabupaten Badung. In Skripsi.

Suryawan, I. N, Eryani, I. G. A. P and Rahadiani, A. A. S. D. 2019. "Perencanaan Bangunan Jetty Dari Bahan Bronjong Pada Muara Sungai Tukad Melangit Di Banjar Tegal Besar Kabupaten Klungkung", PADURAKSA, vol 8 no. 1, pp. 16-26.

Sulaiman, D.M. 2018. Beton Dan Teknologi Pracetak Pada Bangunan Pengaman Pantai. Deepublish Publisher.

Triatmodjo, B., 2011. Perencanaan Bangunan Pantai. Yogyakarta: Beta Offset.

Zamdial, Z., Hartono, D., Bakhtiar, D., \& Nofridiansyah, E. 2017. Studi Identifikasi Kerusakan Wilayah Pesisir Di Kabupaten Mukomuko Provinsi Bengkulu. Jurnal Enggano, 2(2). 